\title{
Factors Affecting Regional Government Financial Statements: Evidence from Indonesia
}

\author{
Bambang Jatmiko \\ Dadang Irawan ${ }^{1}$ \\ Zaky Machmuddah ${ }^{2}$ \\ Titi Laras ${ }^{3}$
}

\begin{abstract}
${ }^{1}$ Faculty of Economic, Universitas Muhammadiyah Yogyakarta, Indonesia
${ }^{2}$ Faculty of Economic and Business, Universitas Dian Nuswantoro Indonesia

${ }^{3}$ Faculty of Economic and Business, Universitas Janabadra Indonesia
\end{abstract}

Doi: 10.36941/ajis-2020-0o26

\begin{abstract}
The purpose of this study is to test and empirically prove the influence of human resource capacity, the application of government accounting standards, the use of information technology, internal control systems, and financial supervision on the quality of information on local government financial statements. The problem in this study is that the quality of information on local government financial reports is still uneven, and the level of compliance with laws and regulations regarding local government financial reporting is lacking. The standards have not been implemented consistently. This research method uses quantitative data by distributing questionnaires. The population in this study is the Regional Government of Brebes Regency with a sample of 40 SKPD offices, and the determination of the sample is based on purposive sampling with the criteria for officials of each SKPD who have authority over the recording, preparation, and reporting of local government finances. The application used to process data in SPSS 25. The method used is the classical assumption test, hypothesis testing, and multiple regression analysis. The results of this study indicate that the Capacity of Human Resources and the Government's Internal Control System has a positive effect on the Quality of Information on the Regional Government's Financial Statements. Application of SAP, Utilization of Information Technology, and Financial Oversight do not affect the Quality of Information on Regional Government Financial Statements.
\end{abstract}

Keywords: regional government, government finances, financial statements

\section{Introduction}

Law number 17 of 2003 concerning State Finances which requires the form and content of the accountability report on the implementation of the State Budget (APBN) or the Regional Budget (APBD) are prepared and presented with the existing Government Accounting Standards. Besides, the government also issued Law number 32 of 2004 concerning the Regional Government and became a reference for issuing Government Regulation (PP) number 24 of 2005 concerning Government Accounting Standards (SAP), then revised to PP number 71 of 2010. SAP is the accounting principles established in preparing and presenting government financial reports, both the 
central and regional governments. An important objective of public sector accounting and administration reform is accountability and transparency in the management of central and local government finances (Yahya, 2006). Regional Government Financial Report (LKPD) is a form of accountability report on regional financial management in the current budget year. Accrual-based Government Accounting Standards (SAP), as set out in PP Number 71 of 2010, become a reference that must be followed in preparing Regional Financial Statements. The regulation is applied to be more accountable and transparent and the quality of financial statements to be better. However, there are still many other factors that influence among them other than the Application of the Standards themselves; there is the Capability of Human Resources and the support of the existing Accounting System. In addition, there are also external factors that can influence it.

Components in the financial statements include the Budget Realization Report, Operational Reports, the excess budget report, the balance sheet, cash flow statement, notes to the financial statements. The Regional Government Financial Report will then be submitted to the DPR / DPRD and the general public after an audit by the Supreme Audit Board (BPK). Financial reports can also be used as a basis for decision making by various parties, so the information contained in the Regional Government Financial Report (LKPD) must be able to support and be useful for users of local government financial information. (Kema, 2013) and (Nurillah, 2014) also believe that information will be helpful if the information can support decision making and can be understood by both internal and external users.

In 2017 based onthe data from 532 LKPD, BPK revealed that there are still face obstacles in implementing the system for each Regional Government. The following are the 2016 LKPD Opinion Data: a) unqualified opinion (WTP): 378 (70\%); b) qualified opinion (WDP): 141 (26\%); c) disclaimer of opinion (TMP): 23 (4\%). The data shows good results for the WTP opinion and has reached the target for regional financial performance in the field of strengthening local government as stipulated in the 2015-2019 RPJMN. However, seeing that there is still a WDP opinion and even TMP for a local government is still a strengthening of financial performance that has not been evenly distributed in all local governments in Indonesia.

The factors that become an obstacle are the understanding of the accounting system it self, the internal control system (SPI) in local governments including the weakness of the accounting and reporting control system, and the weak control system for the implementation of the revenue and expenditure budget. BPK also found and recorded non-compliance with statutory provisions in 63 cases which included records that were not done or inaccurate. The condition resulted in the loss of potential revenue, weaknesses in internal control structures, oversight units internal is not optimal, and SOP has not run optimally.

The summary of problems of SPI weakness occurs: 1) the treasurer of goods does not conduct inventory accordance the provisions; 2) caretaker/storage of goods does not conduct inventory carefully; 3) the local government has not yet integrated the SIMBAKDA and SIMAKDA application; 4) regional government secretary as coordinator of regional financial management and head of the regional financial and wealth management office (DPKKD) have not proposed Qanum related to the complete accrual-based accounting tools and policies; 5) the regional government budget team (TAPD) and the legislative budget agency in preparing APBK are not based on local financial capacity and do not pay attention to guidelines for making APBK; 6) the head of the education and culture office is not careful in controlling and overseeing the management of BOS Funds and Government Assistance Funds and it does not propose budgeting of BOS Funds into the APBD; 7) the head of the apparatus unit (SKPK) does not follow the provisions regarding the management of grants; 8) the head of the related SKPK has not yet thoroughly followed up on the recommendations or the results of the BPK audit. BPK has conducted an examination and has revealed a total of 46 problems of noncompliance with statutory provisions. The following is a list of groups and types of findings by BPK RI for non-compliance with the 2016 legislation. 
Table 1: The findings of BPK RI

\begin{tabular}{|l|c|c|}
\hline \multirow{2}{*}{ Sub-group Findings } & \multicolumn{2}{|c|}{ The Problem } \\
\cline { 2 - 3 } & Amount & $\begin{array}{c}\text { Value } \\
\text { (In Billion) }\end{array}$ \\
\hline Non-compliance with statutory provisions that results in: & 25 & 3,97 \\
\hline Loss & 5 & $\mathbf{1}, 03$ \\
\hline Lack of Acceptance & 30 & 5,00 \\
\hline Sub-total (1) & 16 & - \\
\hline Administrative irregularities (2) & 46 & 5,00 \\
\hline Total non-compliance (1)+(2) & & $\mathbf{1 , 4 0}$ \\
\hline Deposit money or Transfer of Assets to the State / Regional treasury &
\end{tabular}

Source: Inspection Results Summary Data (IHPS) Year 2017 (II), BPK RI.

From the table above, it can be seen that the loss is 3,97 billion, and the lack of revenue is 1,03 billion, which is obtained from non-compliance and administrative irregularities in the management of regional finances. This figure will have an impact on the revenue structure of the APBN and APBD. LKPD's data of Central Java Province, a province where researchers conduct research, is precisely in the Brebes Regency. From the results of BPK's inspection in 2017 IHPS II of 36 districts and cities in Central Java province, the results showed varied opinions; six regencies/cities received WDP opinion, and the remaining 30 received WTP opinion. Brebes Regency, which is the object of research, gets a Fair With Exceptions (WDP) opinion on IHPS I and II; this is the basis for researchers in researching the area. Besides, there is also no research conducted related to the analysis of factors that influence the quality of information on the financial statements of local governments in Brebes Regency.

The objectives of this research are: 1 ) to examine and prove the effectiveness of the capacity of human resources on the quality of information on the financial statements of regional governments empirically; 2) to examine and prove the effect of the implementation of government accounting standards on the Information quality of regional government financial statements; 3 ) to examine and prove the effect of information technology utilization on Information quality of regional government financial statements; 4) to test and prove the effect of the Government's Internal Control System on the quality of information on regional government financial statements; 5 ) to examine and prove the effect of human resources capacity, application of government accounting standards, utilization of information technology, government internal control systems, financial supervision of regional governments on the quality of information on regional government financial statements.

\section{Literature Review and Hypotheses Development}

\subsection{Stewardship Theory}

According to (Donaldson and Davis, 1991), Stewardship Theory explains that circumstances and situations that make management more concernand focus on the interests of the organization rather than individual interests. Assumptions are built on the basis of human nature that can be trusted, responsible, has integrity and beable to be honest with others. This theory explains that good behavior will be carried out by management for the public and stakeholder interests. According to (Segal and Lehrer, 2012), this theory emphasizes the behavior of stewards who do not have personal interests but rather prioritize principal interests. This condition is based on the great attitude of service built by stewards. Serve is an attitude that replaces personal interests with service as the basis for ownership and use of power. Important aspects in achieving organizational goals are behavioral factors, human behavior, human, patterns, and psychological mechanisms (motivation, identification and power) in leading an organization (Donaldson and Davis, 1991). According to Glinkowska and 
Kaczmarek (2015), the most important aspects emphasized in stewardship theory are (1) principals give rewards to stewards, (2) the relationship between principals and stewards is based on trust, (3) the key motivations of stewards give satisfaction in shaping work well, (4) pro-organizational behavior is highly valued, (5) there is no conflict between principal and steward, (6) financial factors are not the main motivation for staff, and (7) there is no reason for principals to implement expensive motivators because the high salary satisfying is enough. Based on the explanation above, it can be interpreted that the Stewardship Theory explains that actions taken by management or government must prioritize the interests of the organization rather than individual interests in the form of good and maximum service.

The meaning of Stewardship Theory in this study is that stewards in this case are the budget managers in the local government expected to work as well as possible for the interests of principals, namely the community and their agencies. Hence, local governments can be trusted to act in accordance with public interests and carry out their duties and functions appropriately, plan and carry out the budget mandated to him, thus the objectives of budget management can be achieved to the maximum. To carry out these responsibilities, stewards are expected to mobilize all capabilities and expertise of human resourceby utilizing the information technology, commitment of all employees involved in budget management so that it is expected to achieve more effective budget management.

\subsection{Hypotheses Development}

\subsubsection{The Effect of Human Resources Capacity on the Quality of Information on Regional Government Financial Statement}

Human resource performance is the ability of a person or individual, an organization (institutional) or a system to carry out its functions or authorities to achieve goals effectively and efficiently (Winidyaningrum, 2009). Human resource capacity must be seen from the ability to produce outputs and outcomes. Human resources are one of the most important organizational elements. Therefore, it must be ensured that the best possible management of human resources is to be able to make optimal contributions in achieving organizational goals (Sukmaningrum, 2012). Human Resources Competency is an ability possessed by an employee related to knowledge, skills, and attitudes in completing performance so as to achieve the desired goals. If human resource competencies are implemented properly, the quality of regional financial reports will improve. Hence, good financial reports can meet the qualitative characteristics of financial statements. Humans who have the competence will be able to complete their work efficiently and effectively. Mahaputra and Putra (2014) in their research proved that human resource competence has a positive effect on the quality of regional financial reports. The evidence of this study is supported by the results of the study (Desianawati, et al, 2014) which states that the competence of human resources has a positive effect on the quality of regional financial reports. Based on the description above, the hypothesis proposed is:

$\mathrm{H}_{1}$ : Human Resources Capacity has a positive effect on the Quality of Information on Regional Government Financial Statements

\subsubsection{The Effect of Application of Government Accounting Standards on Information Quality of Regional Government Financial Statements}

The application of government accounting standards is related to the level of understanding and application of an institution to the regional government accounting system regulations. Government Accounting Standards are set in Government Regulation Number 71 of 2010 amendments to Government Regulation Number 24 of 2005. Government accounting standards are the principles applied in preparing and presenting government financial statements abbreviated as SAP. SAP is 
implemented in the scope of government, namely the central government, regional governments, and organizational units within the central/regional government environment. Mardiasmo (2002) defines accounting standards as guidelines or principles governing accounting treatment in the preparation of financial statements for the purpose of reporting to users of financial statements. Government accounting standards are a reference in preparing financial statements. Therefore, financial accounting standards are an important factor that can improve the quality of financial statements produced. If the government accounting standards have been understood, it will be able to present financial statements consisting of balance sheets, budget realization reports, cash flow statements, and notes to financial statements correctly. Therefore, the government must be able to present financial reports in accordance with government accounting standards. The good quality of regional financial reports will also have an impact on better governance. There search conducted by (Desianawati et al, 2014) shows the results that the application of government accounting standards has a positive and significant effect on the quality of regional financial reports. Based on the explanation above, the hypothesis proposed is:

$\mathrm{H}_{2}$ : The adoption of Government Accounting Standards has a positive effect on the quality of Regional Government Financial Statement Information

\subsubsection{The Effect of Utilization of Information Technology on the Quality of Information on Regional Government Financial Statements}

Minister of Home Affairs Regulation No. 59 of 2007 explains that the regional government accounting system includes a series of procedures starting from the process of collecting data, recording, summarizing, reporting financial in the context of implementing the APBD that can be done manually or using computer applications. Information technology has five main functions (Kadir, 2002), namely collecting data, processing data, reporting data, storing data, and sending data. The main purpose of technology is to provide information for various purposes of managerial activities and the provision of information needed at various levels of operations within the organization. Other than information technology as computer technology (hardware and software) for processing and storing information. It also has functions as a communication technology for disseminating information. Computers as a component of information technology are tools that can multiply the capabilities of humans. Previous research by (Hasyim and Nadzir 2017) revealed that information technology has a direct and significant influence on the quality of local government financial reports. Based on the explanation above, the inconsistency of the variable is still there. Therefore, it is still relevant to be tested again and the proposed hypothesis is:

$\mathrm{H}_{3}$ : The use of information technology has a positive effect on the quality of information on the local government financial statements

\subsubsection{The Effect of Government Internal Control Systems on the Quality of Information on Regional Government Financial Statements}

According to Government Regulation No. 60 of 2008, the internal control system is an integral process of actions and activities carried out continuously by the dream and all employees to provide adequate confidence in the achievement of organizational goals through effective and efficient activities, reliability of financial reporting, security of state assets and compliance with laws and regulations invitation. Improving the quality of the management of state finances can be done through the elements of this internal control system by taking steps such as strengthening supervision, clear separation of duties and functions, delegating authority, documenting complete and legal transactions, recording accurately and on time, and conducting system testing. Existing internal controls to achieve good quality financial statements, these elements must work well. Thus, the internal control system is the foundation of good governance and the first line of defense in combating data and information uncertainty in the preparation of Regional Government Financial 
Statements. The results of the study (DulMuid and Nurillah, 2014) prove empirically that the local government's internal control system influences the quality of local government financial reports. This research is supported by the results of research conducted by (Kiranayanti and Erawati, 2016) and (Putri, 2017) which states that the internal control system has a positive effect on the quality of local government financial reports. Based on the description above, the hypothesis proposed is:

$\mathrm{H}_{4}$ : The Government's Internal Control System has a positive effect on the Quality of Information on Regional Government Financial Statements

\subsubsection{The Effect of Local Government Financial Oversight on the Information Quality of Regional Government Financial Statements}

State finance is regulated in Law No. 17 of 2003 Article 1 which states that state finances are all rights and obligations of the state that can be valued in money, as well as everything in the form of money or goods that can be made into state property in connection with the implementation of these rights and obligations. Whereas supervision is regulated in PP No. 17 of 2005 Article 1, regarding guidelines and guidance for supervising regional government implementation, states that government oversight is a process of activity that is shown to ensure that local governments run according to plans and provisions of applicable laws and regulations. Regional financial oversight is a process of activities aimed at ensuring that local governments run effectively and efficiently in accordance with plans and regulations and regulations (Minister of Home Affairs Regulation No. 51 Year 2010). Supervision is one way to build and maintain the legitimacy of the community to the performance of government by creating an effective system of supervision, both internal control (internal control) and external control (external control). The results of the research (Pratiwi, et. al., 2015) empirically prove that local government financial supervision influences the value of local government financial reporting information. This research is supported by the results of research conducted by (Efendi, et. al., 2017) and (Mansur, et. al., 2017) which states that local government financial supervision influences the quality of local government financial reporting. Based on the description above, the hypothesis proposed is:

$H_{5}$ : Local Government Financial Supervision has a positive effect on the Quality of Information on Regional Government Financial Statements

\section{Research Method}

The object in this study is Brebes Regency and the SKPD researched is 40 with a total of 80 , the research uses purposive sampling technique that is by providing specific criteria to prospective respondents. The independent variables in this research are human resources capacity, application of government accounting standards, utilization of information technology, internal control systems, financial oversight, and dependent variables is information quality of regional government financial statements. The research uses primary data directly obtained from respondents through a questionnaire, and the questions asked in the questionnaire are structured, and respondents are limited to specific answers furthermore, the research using multiple linear regression by SPSS 25 for data analysis. 


\section{Result and Discussion}

Table 2: Research Result

\begin{tabular}{|c|c|c|c|c|c|}
\hline \multicolumn{6}{|c|}{ Coefficients $^{a}$} \\
\hline \multirow{2}{*}{ Model } & \multicolumn{2}{|c|}{ Unstandardized Coefficients } & \multirow{2}{*}{$\frac{\text { Standardized Coefficients }}{\text { Beta }}$} & \multirow{2}{*}{$\mathrm{t}$} & \multirow{2}{*}{ Sig. } \\
\hline & B & Std. Error & & & \\
\hline (Constant) & 1,560 & 13,065 & & 119 & 0,906 \\
\hline Human resource capacity & 0,427 & 0,203 & 0,358 & 2,102 & 0,044 \\
\hline Implementation of SAP & 0,034 & 0,143 & 0,041 & 0,235 & 0,815 \\
\hline Utilization TI & 1,197 & 0,779 & 0,217 & 1,538 & 0,135 \\
\hline SPIP & 0,651 & 0,278 & 0,374 & 2,341 & 0,026 \\
\hline Financial supervision & 0,025 & 0,309 & 0,012 & 0,080 & 0,937 \\
\hline
\end{tabular}

Source: primary data, 2019

4.1 The Effect of Human Resources Capacity on the Quality of Information on Regional Government Financial Statements

Based on the results (see Table 2 ) of the analysis conducted that the value of $b_{1}$ is 0,427 , which means the relationship between the capacity of human resources with the quality of information on local government financial statements has a positive relationship. Human resources is one of the most important organizational elements. The capacity of human resources, including the level of education, expertise, and good experience will be able to make an optimal contribution for achieving organizational goals. With the competence of human resources, it can be known whether a government has carried out its duties and functions professionally, effectively, and efficiently so that the competence of human resources encourage the realization of quality financial reports that are free from material misstatements and misleading understandings (Desianawati, et al., 2014).

The results of regression also show that human resource capacity has positive coefficient $\left(\mathrm{H}_{1}\right)$ on the quality of information on local government financial statements $(\mathrm{Y})$. The result indicates the role of human resources will increase the level the quality of information on the financial statements of the local government in Brebes district. This finding is reinforced by respondents answers to the statement points about knowledge in practice. Almost all respondents understand and know their primary tasks, work techniques by ethics, accounting cycles, and laws so that in the process of preparing financial statements, the local government is very concerned about that matter.

Besides, respondents answers to the statement points about expertise (Skill) almost all of them stating that they know when to post journal, present the balance sheet, budget realization, notes to financial statements, and cash flow must be presented as what is by existing standards. Participation in training related to the preparation and administration of financial statements has also been followed by officials of the Brebes regional government authority and the attitude of the officials which has a high priority to ethics and code of ethics. Other evidence is based on the percentage of respondents' answers to the human resource capacity variable. The results of respondents' answers to the questionnaire which shows the average answer "Agree" or about 58,5\%.

The finding isin line with the results of a study conducted by Mahaputra and Putra (2014) and Desianawati et al. (2014) which states that human resource capacity has a positive effect on the quality of information on local government financial statements. However, the finding is not in line with research by DwiPutri (2017) and Hasyim and Nadzir (2017) that revealed human resource competencies have no significant effect on the quality of local government financial reports. 
4.2 The Effect of Implementation of Government Accounting Standards (SAP) on the Quality of Information on Regional Government Financial Statements

The results (see table 2) of the analysis conducted that the coefficient value of $b_{2}$ is 0,034 , which shows that the relationship between the implementation of SAP with the quality of information on the financial statements of local governments has a positive relationship. However, the results of data processing with regression show that there is no influence between the implementation of SAP $\left(\mathrm{X}_{2}\right)$ on the quality of information on regional financial statements $(\mathrm{Y})$. Based on the results, it means that the implementation of SAP carried out in the Brebes district government is not yet fully optimal and uneven in each SKPD. It proves that the results of respondents answers on understanding and applying SAP are lacking.

Respondents' answers to the adoption SAP show there are still respondents who answered "Never," "Rarely," and "Sometimes," with respectively 2,4\%, 1,1 \%, and 6,6\%. The results of this study are in line with the results of research conducted by (Modo et al., 2016) whose results indicate that understanding of SAP does not significantly influence the quality of information on local government financial statements but opposite with research conducted by (Desianawati et al., 2014). The study clarifies that the application of government accounting standards has a positive and significant effect on the quality of regional financial reports.

The application of SAP is believed to have an impact on improving the quality of financial reporting at the central and regional governments. The adoption of SAP must refer to the Government Regulation Number 71 of 2010 concerning Accrual-based Government Accounting Standards. SAP are guidelines for preparing and presenting financial statements. It is absolute requirement that must be used as a guideline so that the quality of financial statement information in Indonesia and especially within the scope of the Brebes Regency government can be improved (PP No. 71 of 2010). Mardiasmo (2002) states that accounting standards are guidelines or principles governing accounting treatment in the preparation of financial statements to report to the users of financial statements. Government accounting standards are a reference in preparing local government financial reports.

Hence, SAP is an essential factor that can improve the quality of information produced by the regional government's financial statements. If the SAP has been understood, it will be able to present financial statements consisting of balance sheets, budget realization reports, cash flow statements, and notes to financial statements by existing government accounting standards. The quality of useful good regional financial reports will have an impact on better governance (Mahaputra and Putra, 2014).

4.3 The Effect of Utilization of Information Technology on the Quality of Information on Regional Government Financial Statements

Based on the results (see table 2 ) of data processing carried out that the value of $b_{3}$ is 0,197 . It shows that the relationship between information technology utilization and the quality of information on regional government financial reports is positive. However, the results of data processing with regression show the value that there is no influence between the use of information technology $\left(\mathrm{X}_{3}\right)$ on the quality of information on regional financial statements (Y). It means that information technology has not been used optimally both in terms of network and software and it is not yet fully adequate management of information technology within the scope of departments in Brebes Regency.

The primary purpose of technology is the provision of information for various purposes of managerial activities and the provision of information needed at various levels of operation in local government organizations (Muslichah, 2002). The main purpose of technology is to provide information for various levels of managerial activities and the provision of information needed at various levels of operations within local government organizations. Utilization of information 
technology means to use existing information technology in computers, software systems and / or networks and communications.

The use of information technology in the Brebes district government is not yet fully optimal, comprehensive and not evenly distributed in each SKPD. Itis different from the respondent's answer to the questionnaire regarding the use of computers, software, and internet networks that the respondent has been able to use the instruments from the information technology. The results contained in the percentage of respondents' answers to the use of information technology. It also showed results above the average respondent answered "Very Often" (66,7\%) and "Frequently" $(33,3 \%)$.

The results of this research are in line with the results of a study conducted by Mansur. et al. (2017) which shows the effects results that the use of information technology does not affect the value of local government financial reporting information. However, the research conducted by (Hasyim and Nadzir 2017), which shows the results that the use of information technology has a significant direct effect on the quality of local government financial reports.

\subsection{The Effect of Government Internal Control Systems on the Quality of Information on Regional Government Financial Statements}

Based on the results (see table 2 ) of the analysis conducted that the value of $b_{4}$ is 0,651 , which shows that the relationship between the government's internal control system and the quality of information on the financial statements of the regional government has a positive relationship. The results of regression also show that there is a positive influence between the government's internal control system $\left(\mathrm{H}_{4}\right)$ on the quality of information on regional government financial statements $(\mathrm{Y})$. The better the Government's Internal Control System, the better the quality of information on the financial statements of the Brebes district government. Based on the results and explanations above, it means that the internal control system in the Brebes district government has been adequate and able to be implemented to improve the quality of information on the financial statements of regional governments.

Almost all respondents understood and implemented an internal control system that includes a controlled environment, risk assessment and management, control activities, information and communication, and monitoring conducted by the leadership, $63 \%$ of respondent said "agree". The results of this study are in line with the results of the research conducted by (Kiranayanti and Erawati, 2016) which states that the internal control system has a positive effect on the quality of local government financial reports but contradict with research by Mansur et al., (2017) shows the results that the government's internal control system does not affect the value of local government financial reporting information.

According to government regulation Number 60 of 2008, the internal control system is an integral process of actions and activities carried out continuously by the leadership and all employees to provide adequate confidence for the achievement of organizational goals through effective and efficient activities, reliability of financial reporting, security of state assets, and compliance with regulations legislation.

Improving the quality of state financial management can be done through elements of the internal control system by taking steps such as strengthening supervision, clear separation of duties and functions, delegating authority, documenting complete and legal transactions, recording accurately and on time, and testing the control system. To achieve agood report information quality, these elements must work well (Mahaputra and Putra, 2014).

Thus, the internal control system is the foundation of good governance and the first line of defense against the invalidity of data and information in the preparation of local government financial reports. However, it can be concluded that the better government's internal control system has, the better quality of government financial statement information will produce. 


\subsection{The Effect of Regional Government Financial Oversight on the Quality of Information on Regional Government Financial Statements}

Based on the results (see table 2 ) of the data processing carried out that the value of $b_{5}$ is 0,025 , which indicates that the relationship between regional government financial oversight and the quality of information on regional government financial statements is positive. However, the results of data processing with regression show that there is no influence between regional government financial oversight $\left(\mathrm{X}_{5}\right)$ on the quality of local government financial statement information $(\mathrm{Y})$. The average of respondents answering "Agree" (73,1\%) and "Strongly Agree" (20,6\%) and the remainder who answer "Don't know." "Disagree" and "Strongly Disagree."

It means that financial supervision conducted within the scope of the Brebes district government has not been running optimally, effectively, and efficiently. However, the regional government financial supervision that has been carried out has not been able to improve the quality of the financial statements of the Brebes regency government financial information. In the regional government of the Brebes Regency, it is not entirely optimal, comprehensive, and not evenly distributed in each SKPD. This is proven by the respondent's answers that still have the explanation to Strongly Disagree, Disagree, and Don't Know.

Regional financial supervision is an activity process whose purpose is to ensure that the local government runs effectively and efficiently in accordance with the plans and provisions of laws and regulations (Permendagri No. 51 of 2010). Financial oversight is one way to build and maintain the legitimacy of the community towards government performance by creating a system of internal supervision and external supervision. Mardiasmo (2004) states that with effective and systematic supervision of regional financial management, financial reporting which is a form of government accountability is able to ensure that the information presented in the financial reporting is valid. Then, it can be concluded that the better the local government financial supervision system, the better the quality of financial statement information produced.

The results of this study are in line with the results of research conducted by (Mansur et al., 2017) which shows the results that regional government financial supervision does not affect the value of local government financial reporting information. The research is not in line with a study conducted by (Efendi et al., 2017), which states that regional government financial oversight influences the quality of local government financial reporting.

\section{Conclusion}

The conclusions that can be drawn from this study are: the capacity of human resources and the government's internal control system has a positive effect on the quality of information on local government financial statements. However, the adoption of government accounting standards, the use of information technology, and local government financial oversight does not affect the quality of information on local government financial statements.

The impact of this study, the local governments becomes more compliant and understands what must exist and be made in the preparation of financial reporting. Appropriate financial reporting arrangements will have an impact on local revenue and potential revenue increases, and the effectiveness and efficiency of the budget can be optimized. Furthermore, those will have an impact on the economic development of the community.

\section{References}

Desianawati K., Herawati N.T., \& Sinarwati N.K. (2014). The Effect of HR Competence, SAP Application, and Regional Financial Accounting Systems on the Quality of Regional Financial Statement..E-Journal S1 Accounting Universitas Pendidikan Ganesha, Vol. 2(1), 1-11. 
Donaldson, L., \& Davis, J.H. (1991). Stewardship theory or agency theory: CEO governance and shareholder returns. Asutralian Journal of Management, 16, 49-64.

Evicahyani, S.I dkk., (2016). Analysis of the factors that affect the quality of the financial statements of the Tabanan district government. E-Journal Economic and Business Universitas Udayana. Vol 5(3), 403-428.

Efendi L., Darwanis, Abdullah S. (2017). Factors that influence the quality of regional financial reporting study on SKPD Aceh Tengah District. Journal Economic Perspective Darussalam. Vol 3(2), 182-195.

Freeman, R et al. (2010). The Stakeholder Theory: The State of The Art. Cambridge: Cambridge University Press.

Friskianti, Y. \& Handayani, B.D. (2014). Accounting Analysis Journal, Vol 3 (1), 361-369.

Glinkowska, B, \& B Kaczmarek. (2015). Classical and Modern Concepts of Corporate Governance (Stewardship Theory and Agency Theory). Management 19 (2): 84-93

Hariyanto, A. (2015). The Use of Accrual Bases in Government Accounting in Indonesia. Darma Economic, Vol. 19 (36), 1-11.

Harlinda. (2016). Analysis of the factors that affect the quality of information on the financial statements of the regional government empirical study district / city of Riau. Journal Sorot Unri. Vol 11 (2), 127-144.

Hasyim. R \& Nadzir. (2017). The Influence of Information Technology Utilization, Human Resources Competence on the Quality of Regional Government Financial Statements with Intervening Variables Based on AccrualBased Government Accounting (Empirical Study in Barru District Government). Akuntabel, 14 (1), 57-68.

Herman L A., Daswirman. (2017). Analysis of the factors that affect the quality of local government financial reports, empirical studies on the Payakumbuh city government. Journal Pundi, Vol 1 (2), 119-13o.

Ihsanti, E., (2014). The Effect of Human Resource Competence and the Implementation of Regional Financial Accounting Systems on the Quality of Regional Financial Statements (Empirical Study on SKPD of District of Fifty City. http://ejournal.unp.ac.id/students/index.php/akt/article/view/1057

Indonesian government. (2003). Law No. 17 of 2003 on State Finance. RI State Gazette of 2003, No. 4286. RI State Secretariat. Jakarta.

Indonesian government. (2004). Law No. 32 of 2004 on Regional Government. Republic of Indonesia State Gazette Year 2004, No. 4437. RI State Secretariat. Jakarta.

Indonesian government. (2005). Government Regulation No. 24 of 2005 on Government Accounting Standards (SAP). Republic of Indonesia State Gazette Year 2005, No. 4503. RI State Secretariat. Jakarta.

Indonesian government. (2010). Government Regulation No. 71 of 2010 on Accrual-based Government Accounting Standards. Republic of Indonesia State Gazette Year 2010, No. 123. RI State Secretariat. Jakarta.

Indonesian government. (2006). Government Regulation No.8 of 2006 concerning Financial Reporting and Performance of Government Agencies. Republic of Indonesia. State Gazette Year 2006, No. 25. RI State Secretariat. Jakarta.

Indonesian government. (2006). Permendagri No. 13 of 2006 on Guidelines for Regional Financial Management. Republic of Indonesia Ministry of Home Affairs. Jakarta

Indonesian government. (20o8). Government Regulation No. 60 of 2008 on Government Internal Control Systems. RI State Gazette, No. 127. Secretariat of State.

Indonesian government. (2007). Permendagri No. 59 of 2007 on Guidelines for Regional Financial Management. Republic of Indonesia Ministry of Home Affairs. Jakarta.

Indonesian government. (2010). Permendagri No. 51 of 2010 on Guidelines for Supervision of the Implementation of Regional Government. Republic of Indonesia Ministry of Home Affairs. Jakarta.

Indonesian government. (2010). Government Regulation No. 65 of 2010 on Regional Government Financial Information Systems. RI State Gazette, No. 110. State Secretariat. Jakarta.

Kadir Abdul. (2002). Introduction to Information Systems. Publisher Andi Yogyakarta: Yogyakarta

Kadir, A. dan T. Ch. Triwahyuni. (2013). Introduction to Information Technology Revised Edition. Yogyakarta.

KemaIhwan. (2013). Presentation of Regional Financial Statements based on Government Accounting Standards on the Government of the City of Manado. Journal EMBA. Vol 1 (3), 771-781.

Kiranayanti, I. A.E \& Erawati, N.M.A. (2016). The Influence of Human Resources, Internal Control, Understanding of the Accrual Basis of the Quality of Regional Financial Statements. E-Journal Accounting Universitas Udayana. Vol. 16 (2), 1290-1318.

https://ojs.unud.ac.id/index.php/Akuntansi/article/view/18075

Lupia, Arthur \& Mathew McCubbins. (200o). "Representation or abdication? How citizens use institutions to help delegation succeed. European Journal of Political Research 37: 291-307.

Madiguna, T. (2018). Analysis of the factors affecting the quality of the financial statements of Karangasem district government. E-Journal Accounting Universitas Udayana. Vol 23 (2), 1253-1276.

Mahaputra, I P.U \& Putra, I.W. (2014). Analysis of factors affecting the quality of local government financial reporting information. E-Journal Accounting Universitas Udayana Vol 8 (2): 230-244. 
Mahmudi. (2010). Analysis of Regional Government Financial Statements. Second Edition. UPP STIM YKPN. Yogyakarta.

Mansur, F. Prasetyo. E. Maiyami R. (2017). Analysis of the factors affecting the value of local government financial reporting information. Journal of Applied Accounting and Taxation Vol. 2 (2), 143-152.

Mardiasmo. (2001). Oversight, Control and Examination of Government Performance in implementing regional autonomy. Journal Business and Accounting. 3 (2).

Mardiasmo. (2002). Public Sector Accounting. Publisher Andi. Yogyakarta.

Mardiasmo. (2004). Public Sector Accounting. Publisher Andi. Yogyakarta.

Modo, S.M dkk. (2016). Analysis of the factors that influence the quality of local government financial statement information (Empirical study of Talaud district). Journal Accounting Research and Auditing Goodwill. Vol 7 (2), 14-30.

Moeller, Robert R., (2007). COSO Enterprise Risk Management: Understanding the New Integrated ERM Framework. New Jersey: John Wiley \& Sons, Inc.

Muslichah. (2002). The effect of information technology, interdependence, characteristics of management accounting systems on managerial performance. Journal Accounting Petra. 4 (2), 106-125.

Nurillah, A.S. \& Muid, D. (2014). Influence of human resource competencies, implementation of regional financial accounting systems (SKPD), utilization of information technology, and internal control systems on the quality of local government financial reports (empirical studies on Depok city SKPD). 3, 1-13.

Putri, R. D., (2017). The influence of the quality of human resources and the use of information technology and inter-control of the value of local government financial reporting information. Journal Economic and Business Dharma Andalas. 18 (1), 19-39.

Pratiwi, R.P. Adiputra, I.M.P. Atmadja, A.W.T., (2015). The effect of regional financial supervision, human resources, utilization of information technology and internal accounting control systems on the value of local government financial reporting information" (case study on Tabanan regency SKPD). E-Journal S1 Accounting Universitas Pendidikan Ganesha, Vol 3 (1), 1-12.

Rahmawati, N., (2014). Implementation of accrual-based government accounting standards in the secretariat of the Malang Regency DPRD based on government regulation number 71 of 2010.

Segal, L., \& Lehrer, M. (2012). “ The Institutionalization of Stewardship: Theory, Propositions, and Insights from Change in the Edmonton Public Schools. Organization Studies", 33 (2), 169-201.

Surastiani, D.P dkk. (2015). Analysis of factors that affect the quality of information on local government financial statements. Journal Dinamica Unnes. Vol 7 (2), 139-149.

Tickell, G. (2010). Cash To Accrual Accounting: One Nation's Dilemma. The International Business \& Economics Research Journal. 9 (11), 71-78.

Wilkinson Joseph W. (2005). Accounting and Information Systems. Publisher Erlangga. Yogyakarta.

Wilkinson, Joseph W. Et al. (2005). Accounting Information System Essential Concept and Application, 4 Edition, John Willey \& Sons Inc, New York-USA.

Winindyaningrum \& Rahmawati. (2009). The Influence of Human Resources and Utilization of Information Technology on the Reliability and Timeliness of Regional Government Financial Reporting with intervening variables Internal Control of Accounting. Symposium Nationaly XIII. Purwokerto. Vol 18 No 1.

Yahya, Idhar. (2006). Accountability and Transparency in Regional Financial Management. Journal System Technical Industry, Vol 7 (4), 27-29. 